\title{
Radio- and photosensitization of DNA with compounds containing platinum and bromine atoms ${ }^{\star}$
}

\author{
Małgorzata A. Śmiałek ${ }^{1,2, a}$, Sylwia Ptasińska ${ }^{3}$, Jason Gow ${ }^{2}$, Søren Vrønning Hoffmann ${ }^{4}$, and Nigel J. Mason² \\ ${ }^{1}$ Gdańsk University of Technology, Faculty of Ocean Engineering and Ship Technology, Department of Control and Energy \\ Engineering, G. Narutowicza 11/12, 80-233 Gdańsk, Poland \\ 2 Department of Physical Sciences, The Open University, MK7 6AA, Milton Keynes, UK \\ 3 Radiation Laboratory and Department of Physics, University of Notre Dame, Notre Dame, 46556, IN, USA \\ 4 ISA, Department of Physics and Astronomy, Aarhus University, 8000 Aarhus C, Denmark
}

Received 19 January 2015 / Received in final form 23 March 2015

Published online 5 May 2015

(C) The Author(s) 2015. This article is published with open access at Springerlink.com

\begin{abstract}
Irradiations of plasmid DNA by both X-rays and UV light in the presence and absence of compounds containing platinum and bromine atoms were performed in order to asses the sensitization potential of these compounds. Plasmid DNA pBR322 was incubated with platinum (II) bromide, hydrogen hexabromoplatinate (IV), hydrogen hexahydroxyplatinate (IV) and sodium hexahydroxyplatinate (IV). Incubation was followed by X-ray or UV irradiations. It was found that amongst the sensitizers tested, during irradiations carried out in the presence of platinum (II) bromide, the highest levels of double strand breaks formation upon X-ray treatment were recorded. In contrast much less damage was induced by UV light. Data presented here suggests that this compound may be a promising radiosensitizer for cancer treatment.
\end{abstract}

\section{Introduction}

A comprehensive understanding of the mechanisms by which high- and low-energy radiation interacts with cellular components, DNA in particular, underlays advances in modern radiotherapy. For many years attempts were made to increase the levels of lethal cellular damage in a controlled manner using various types of drugs, that apart from chemical damage, may act as radiosensitizers. Such concomitant treatment has been shown to be particularly beneficial in the treatment of neck, lung, pancreas or stomach cancers [1].

However the mechanisms by which such radiosensitization occurs are still unclear. Recent research has highlighted that low-energy electrons, which are the most abundant species created during high energy irradiations, may be as efficient in causing damage to DNA [2], as the incident radiation itself. Such secondary-particle damage can be initiated by any type of ionizing radiation, such as $\mathrm{X}$-rays or $\gamma$-rays. Accordingly a wide range of radiosensitizing compounds are being investigated, amongst which platinum-based ones have been found to be the most successful $[3,4]$. It has been shown that such compounds coordinate themselves to nitrogen atoms of purines in DNA

\footnotetext{
* Contribution to the Topical Issue "COST Action NanoIBCT: Nano-scale Processes Behind Ion-Beam Cancer Therapy", edited by Andrey Solov'yov, Nigel Mason, Gustavo García, Eugene Surdutovich.

a e-mail: smialek@pg.gda.pl
}

helix [3]. One of the most widely used cancer-therapy drugs is cisplatin, which apart from being a very efficient chemotherapeutic drug, toxic to living cells [5], can be also used as a potential source of secondary particles, mainly low energy electrons and radicals, emitted upon interaction with high-energy radiation. This property of cisplatin was investigated recently and an increase in single (SSB) and double strand breaks (DSB) formation was reported [6].

The enhancement of DNA damage upon Pt-resonant $\mathrm{X}$-ray radiation in presence of platinum-derived complexes due to the Auger effects has been widely investigated $[7,8]$, showing that DNA damage increases upon platinum adducts. Apart from platinum-containing drugs [9], brominated compounds $[10,11]$ were also found to be efficient radio- and photosensitizers in clinical radiotherapy. Therefore, an even more efficient drug may be developed if it contains both platinum and bromine, although to our best knowledge, such studies have not yet been performed. In our previous studies we showed that one of these compounds, $\mathrm{PtBr}_{2}$, causes increased radiosensitivity in plasmid DNA, when compared with widely-used cisplatin [12]. This enhancement can be attributed to dissociative electron attachment to $\mathrm{PtBr}_{2}$ and bromide anion formation [13]. In the present work we investigate three other platinum (IV) compounds as possible candidates for therapeutic drugs and cross examine them against $\mathrm{PtBr}_{2}$ (Fig. 1). The reason for choosing the compounds used in our study was both low complexicity of the molecules 
<smiles>[NH3+][NH3+]</smiles>

3.

Fig. 1. Compounds investigated as potential radio- and photosensitizers: (1) $\mathrm{PtBr}_{2}$, (2) $\mathrm{H}_{2} \mathrm{PtBr}_{6}$, (3) $\mathrm{Na}_{2} \mathrm{Pt}(\mathrm{OH})_{6}$ and (4) $\mathrm{H}_{2} \mathrm{Pt}(\mathrm{OH})_{6}$.

themselves as well as lack of large functional groups that may alter the results of simple $\mathrm{Pt}-\mathrm{Br}$ compound and radiation interaction.

\section{Methodology}

\subsection{Plasmid DNA}

To model cellular DNA damage, plasmid DNA pBR322 was used. Plasmid DNA was prepared using a procedure previously described in detail [14] and suspended in ultrahigh purity (UHP) $\mathrm{H}_{2} \mathrm{O}$ with $\mathrm{pH}$ adjusted to 8.0 with $1 \mathrm{M}$ $\mathrm{NaOH}$. This plasmid has already been widely used in numerous irradiation studies $[15,16]$. Sodium hydroxide was chosen to stabilize plasmid DNA under vacuum conditions as it was shown that a lack of cations in the vicinity of phosphate backbone in DNA solution prior to solvent evaporation leads to DNA strand breaks and is due to constituent water removal from DNA [17].

\subsection{Sample preparation and analysis}

Two compounds containing both platinum and bromine atoms were chosen to be tested as potential radiosensitisers: platinum (II) bromide $\left(\mathrm{PtBr}_{2}\right)$ and hydrogen hexabromoplatinate (IV) $\left(\mathrm{H}_{2} \mathrm{PtBr}_{6}\right)$. Additionally, two similar compounds, containing platinum and lacking bromine ions: hydrogen hexahydroxyplatinate (IV) $\left(\mathrm{H}_{2} \mathrm{Pt}(\mathrm{OH})_{6}\right)$ together with sodium hexahydroxyplatinate (IV) $\left(\mathrm{Na}_{2} \mathrm{Pt}(\mathrm{OH})_{6}\right)$ were tested. The compounds and reagents were purchased from Sigma-Aldrich, UK. $\mathrm{H}_{2} \mathrm{Pt}(\mathrm{OH})_{6}$ and $\mathrm{Na}_{2} \mathrm{Pt}(\mathrm{OH})_{6}$ were chosen to serve as a reference for $\mathrm{H}_{2} \mathrm{PtBr}_{6}$ and allowed us to quantify the damage induced upon irradiation due to addition of bromide ions. Derivatives of $\mathrm{Pt}(\mathrm{IV})$ and $\mathrm{Pt}(\mathrm{II})$ were selected to see if the radiation damage enhanced by a $\mathrm{Pt}(\mathrm{II})$ compound

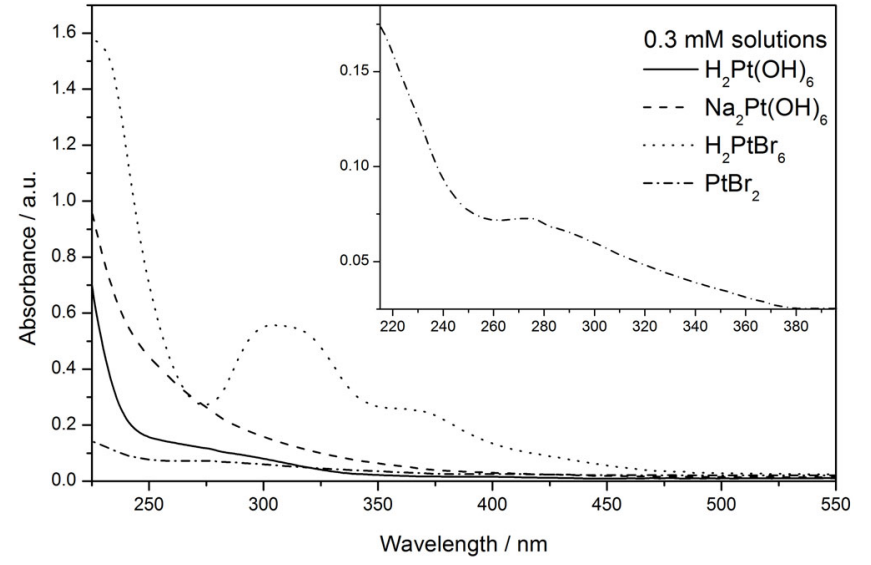

Fig. 2. The UV absorption spectra of $0.3 \mathrm{mM}$ solutions of $\mathrm{H}_{2} \mathrm{Pt}(\mathrm{OH})_{6}, \mathrm{Na}_{2} \mathrm{Pt}(\mathrm{OH})_{6}, \mathrm{H}_{2} \mathrm{PtBr}_{6}$ and $\mathrm{PtBr}_{2}$.

with associated bromide ions is any different to $\mathrm{Pt}(\mathrm{IV})$ based compounds.

All compounds were dissolved in UHP water to obtain $0.3 \mathrm{mM}$ solutions. The $\mathrm{pH}$ of all solutions was measured and, when necessary, adjusted to 7.5-8.5 (the working range for reactions involving DNA) with $1 \mathrm{M}$ sodium hydroxide. All solutions were filtrated through a $0.2 \mathrm{mi}-$ cron syringe filter.

The absorption spectra of these solutions were recorded in order to assess any possible absorption bands in the UV region of the light used later for irradiation. These spectra are shown in Figure 2. Complexing of DNA and Pt compounds of interest was performed in the following way: $1 \mu \mathrm{g}$ (0.35 pmoles) of plasmid DNA, which contains 824 pmoles of guanine bases, was incubated with 3 nmoles of each compound (guanine binding site saturation conditions) in $20 \mu \mathrm{l}$ of the total volume of the reaction at $37^{\circ} \mathrm{C}$ for 9 hours. Additionally, some pure DNA was also kept under the same conditions to serve as control samples in the irradiation experiments.

Each complex was irradiated and analyzed in triplicate and the error bars shown in all figures represent the standard deviation of the population. It was observed that, in most cases, the long-term incubation of DNA at $37^{\circ} \mathrm{C}$ introduced at most $2 \%$ loss of supercoiled form of DNA but in the case of $\mathrm{PtBr}_{2} 5 \%$ damage was noted (Fig. 3). For the X-ray study all samples were also vacuum-dried onto freshly cleaved mica at room temperature [18] with a small diaphragm pump and then transferred into a vacuum chamber. Loss of initial form of plasmid DNA due to that procedure is also shown in Figure 3 for $\mathrm{PtBr}_{2}$, since in this case the overall loss was similar for all adducts.

Additionally, three reference samples were kept under high vacuum (HV) conditions $\left(10^{-6}\right.$ mbar) for the period of time corresponding to the largest irradiation dose during the experiment. Figure 3 shows $13 \%$ loss of the initial DNA: $8 \%$ due to placing samples on mica surface and additional $5 \%$ coming from the HV conditions.

After irradiation all the DNA complex samples were recovered from mica with $5 \mu \mathrm{l}$ of TE buffer and analyzed via agarose gel electrophoresis (AGE, $1.2 \%$ gels, $1 \times$ TBE, 


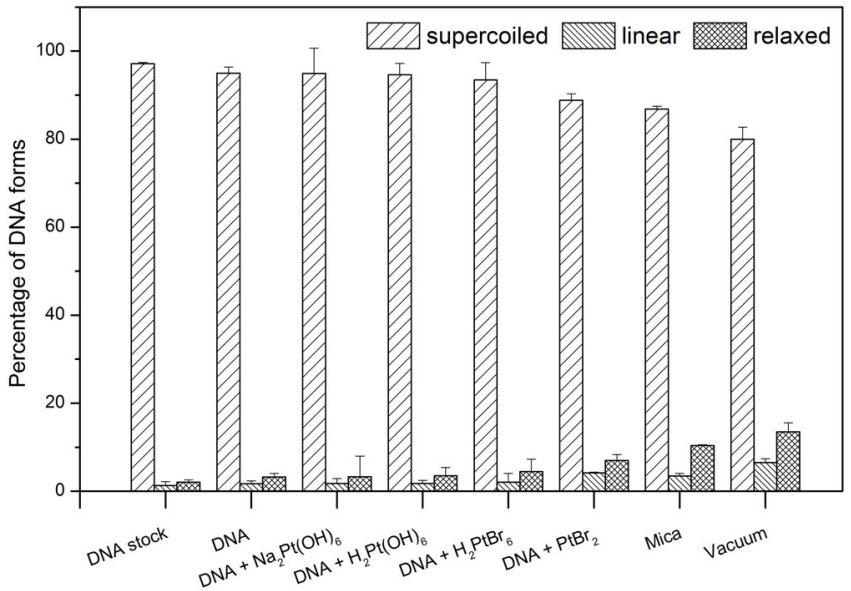

Fig. 3. Damage induced to plasmid DNA through the preparation procedure; quantities of main plasmid forms detected (from left) in: the stock solution; stock solution incubated at $37{ }^{\circ} \mathrm{C}$ for $9 \mathrm{~h}$; stock solution mixed with $\mathrm{Na}_{2} \mathrm{Pt}(\mathrm{OH})_{6}$, inc. for $9 \mathrm{~h}$ at $37^{\circ} \mathrm{C}$; stock solution mixed with $\mathrm{H}_{2} \mathrm{Pt}(\mathrm{OH})_{6}$, inc. for $9 \mathrm{~h}$ at $37^{\circ} \mathrm{C}$; stock solution mixed with $\mathrm{H}_{2} \mathrm{PtBr}_{6}$, inc. for $9 \mathrm{~h}$ at $37^{\circ} \mathrm{C}$; stock solution mixed with $\mathrm{PtBr}_{2}$, inc. for $9 \mathrm{~h}$ at $37^{\circ} \mathrm{C}$; stock solution mixed with $\mathrm{PtBr}_{2}$, inc. for $9 \mathrm{~h}$ at $37^{\circ} \mathrm{C}$, vacuumdried on mica and stock solution mixed with $\mathrm{PtBr}_{2}$, inc. for $9 \mathrm{~h}$ at $37{ }^{\circ} \mathrm{C}$, vacuum-dried on mica and kept under irradiation conditions for $20 \mathrm{~min}$ (no irradiation).

$2 \mathrm{~V} / \mathrm{cm}$, stained later with a SYBR Green I dye and destained with a running buffer).

In the UV light studies, $2 \mu \mathrm{l}$ of DNA solution with a sensitizing compound were irradiated as a liquid and collected after irradiation for further analysis.

\subsection{DNA irradiations}

The DNA samples were irradiated at various doses in triplicate using both X-rays and UV light. UV studies were performed on the UV1 beamline at ISA, Centre for Storage Ring Facilities at Aarhus University, Denmark, using a wet cell setup described previously [14]. Samples were irradiated as liquid with the maximum dose up to 25 Gy using various wavelengths. Wavelengths of irradiations for all compounds were chosen predominantly based on the photoabsorption spectra, shown in Figure 2. DNA mixed with $\mathrm{Na}_{2} \mathrm{Pt}(\mathrm{OH})_{6}$, irradiated with UV light at $215,260,320$ and $370 \mathrm{~nm}$. DNA mixed with $\mathrm{H}_{2} \mathrm{Pt}(\mathrm{OH})_{6}$ was irradiated at 215, 280 and $370 \mathrm{~nm}$, while DNA mixed with $\mathrm{H}_{2} \mathrm{PtBr}_{6}$ - at 225, 305, 370 and $425 \mathrm{~nm}$. For DNA mixed with $\mathrm{PtBr}_{2}$, irradiations were carried at 208, 215, 260 and $370 \mathrm{~nm}$, whereas pure DNA was irradiated at 208, 215, 260 and $370 \mathrm{~nm}$.

For the X-ray study, an X-ray tube with a tungsten anode was used, with a tube potential of $25 \mathrm{kV}$ and a current of $0.50 \mathrm{~mA}$ to provide a continuous X-ray spectrum. The X-ray tube was capable of delivering a dose rate of $\sim 11.5 \mathrm{mGy} / \mathrm{s}$. Such set-up allowed irradiation of the samples with low energy X-rays, knowing that predominant lines in the spectrum will be $\mathrm{L} \alpha, \mathrm{L} \beta$ and $\mathrm{M} \alpha$ with energies approximately equal to $8.36 \mathrm{keV}, 9.8 \mathrm{keV}$ and $1.8 \mathrm{keV}$, respectively.

\section{Results}

\subsection{UV irradiations}

The results of UV irradiation of DNA samples mixed with $\mathrm{Na}_{2} \mathrm{Pt}(\mathrm{OH})_{6}, \mathrm{PtBr}_{2}, \mathrm{H}_{2} \mathrm{PtBr}_{6}, \mathrm{H}_{2} \mathrm{Pt}(\mathrm{OH})_{6}$ and pure DNA are shown in Figure 4. In all cases low levels of loss of supercoiled DNA form was observed, resulting in formation of only the relaxed DNA form (SSBs). No DSBs were detected upon UV irradiation. For pure DNA, damage of less than $8 \%$ was observed at all UV wavelengths used for irradiation. Higher levels of damage, obtained for irradiation of all samples at $370 \mathrm{~nm}$ were attributed to second order synchrotron radiation. In addition, no dimer formation was detected in samples irradiated in presence and absence of siensitizing compounds.

\subsection{X-ray irradiations}

Figure 5 shows the loss of supercoiled form of DNA with increasing dose of radiation, whereas in Figures 6 and 7 the appearance of linear DNA and relaxed forms is shown, respectively. In all cases the addition of platinum increases the radiation damage when compared to pure DNA, but the presence of bromine groups can enhance the damage even more.

The highest levels of damage are obtained for DNA samples incubated in presence of $\mathrm{PtBr}_{2}$. Also the exchange of hydroxyl groups in $\mathrm{H}_{2} \mathrm{Pt}(\mathrm{OH})_{6}$ to bromine ions $\left(\mathrm{H}_{2} \mathrm{PtBr}_{6}\right)$ resulted in some enhancement in damage levels, mostly converted to DSBs (Figs. 6 and 7).

Relatively high levels of damage were observed for samples incubated with sodium hexahydroxyplatinate (IV). The levels of supercoiled DNA loss were twice as high at 7 Gy as in case where a corresponding acid was used as a sensitizer.

\section{Discussion and conclusions}

In case of all compounds tested the amount of damage induced by UV light was small if not negligible, not exceeding $10 \%$ of supercoiled DNA loss and no DSB were measured.

In contrast considerable damage was observed when these complexes were irradiated with similar doses of X-rays. Levels of supercoiled DNA loss reach $15 \%$ with 7 Gy for hydrogen hexahydroxyplatinate (IV). When hydroxyl groups in this compound were substituted with bromine atoms, interestingly this damage was observed even after lowest radiation dose of 2 Gy was applied, nonetheless at 7 Gy hardly any increase with respect to unbrominated analogue can be observed.

A vast increase in damage levels can be observed when sodium hexahydroxyplatinate (IV) was used. At radiation dose of 7 Gy over $15 \%$ increase in loss of supercoiled DNA was seen with respect to samples incubated with hydrogen hexahydroxyplatinate (IV). As in case of other platinum hydroxyl compound, loss of supercoiled DNA form arises more steadily with applied radiation dose, than in case of 


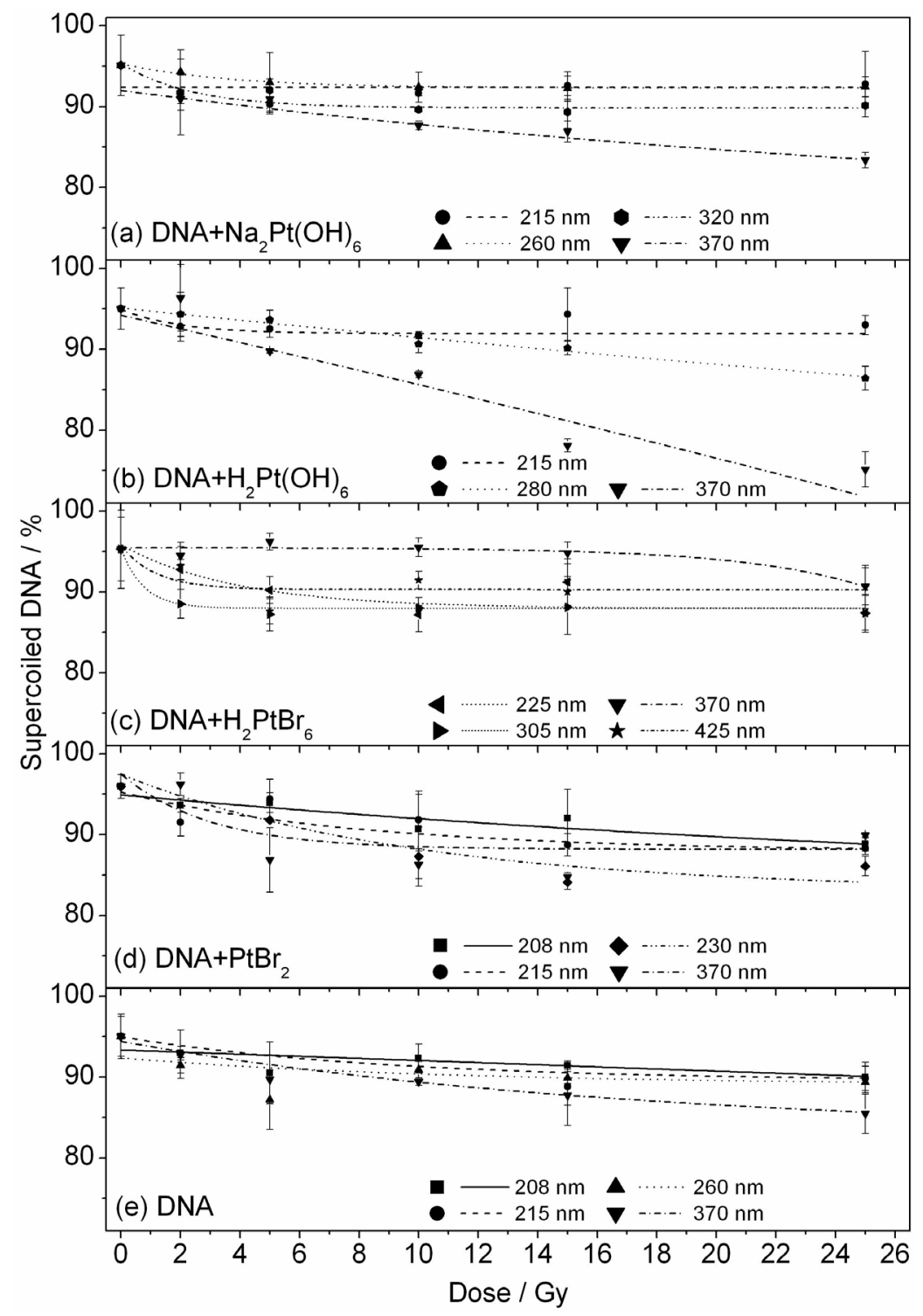

Fig. 4. Supercoiled DNA loss as a function of UV radiation dose at various wavelengths for DNA samples incubated for $9 \mathrm{~h}$ with $300 \mu \mathrm{M}$ solutions of (a) $\mathrm{Na}_{2} \mathrm{Pt}(\mathrm{OH})_{6}$, (b) $\mathrm{H}_{2} \mathrm{Pt}(\mathrm{OH})_{6}$, (c) $\mathrm{H}_{2} \mathrm{PtBr}_{6}$ and (d) $\mathrm{PtBr}_{2}$ and for pure DNA (e). Curves represent exponential decay function fit to experimental data.

brominated derivative and even up to $30 \%$ loss of supercoiled DNA (7 Gy) can be obtained without employing bromine.

Moreover, irradiation carried out in the presence of $\mathrm{PtBr}_{2}$ shows even greater damage induced with respect to pure plasmid molecules (60\% at 7 Gy). Damage levels observed in this case are substantial even for low doses of radiation, like in case of hydrogen hexahydroxyplatinate (IV).

All of the dose-response curves could be fitted with simple exponential decay functions, thus it can be assumed that the DNA films were penetrated by the incident radiation with no loss of photon intensity through the film.

The irradiated brominated compounds also reveal a considerable increase in levels of the DSBs. Interestingly, the brominated derivative of $\mathrm{Pt}$ (IV) seemed to cause hardly any relaxation, i.e., SSBs, in DNA molecules; however, up to $25 \%$ linear form was detected.

Our results show that a combination of $\mathrm{Pt}$ and $\mathrm{Br}$ atoms is much more efficient in radiosensitizing DNA to $\mathrm{X}$-ray radiation than $\mathrm{Pt}$ alone-based compounds. Comparing our results with the ones obtained for cisplatin and its brominated analog [12], it can be seen that for compounds irradiated in the presence of $\mathrm{PtBr}_{2}$, radiation damage is significant also at lower radiation doses. Apart from an increase of SSBs levels, a substantial increase in DSBs levels was observed for compounds with $\mathrm{Pt}$ and $\mathrm{Br}$ atoms used here, which is an important feature for a potential radiosensitizer. For the investigated $\mathrm{PtBr}_{2}$ compound this increase was almost 7 -fold higher than the initial $5 \%$ of damage, which had not change over the irradiation time period, whereas for $\mathrm{H}_{2} \mathrm{PtBr}_{6}$ the damage increased 4 times 


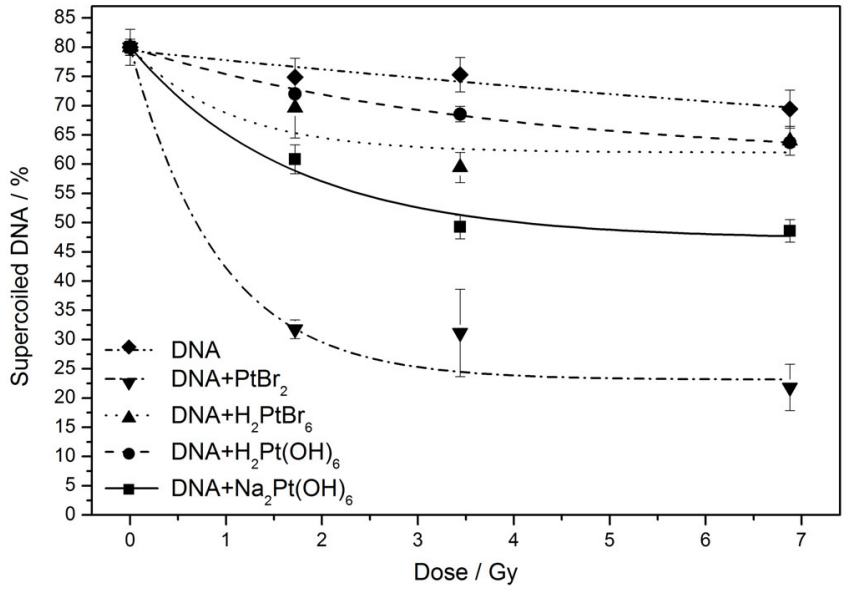

Fig. 5. Supercoiled DNA loss as a function of X-ray radiation dose for pure DNA and DNA with platinum compounds attached. Curves represent exponential decay functions fit to the experimental data.

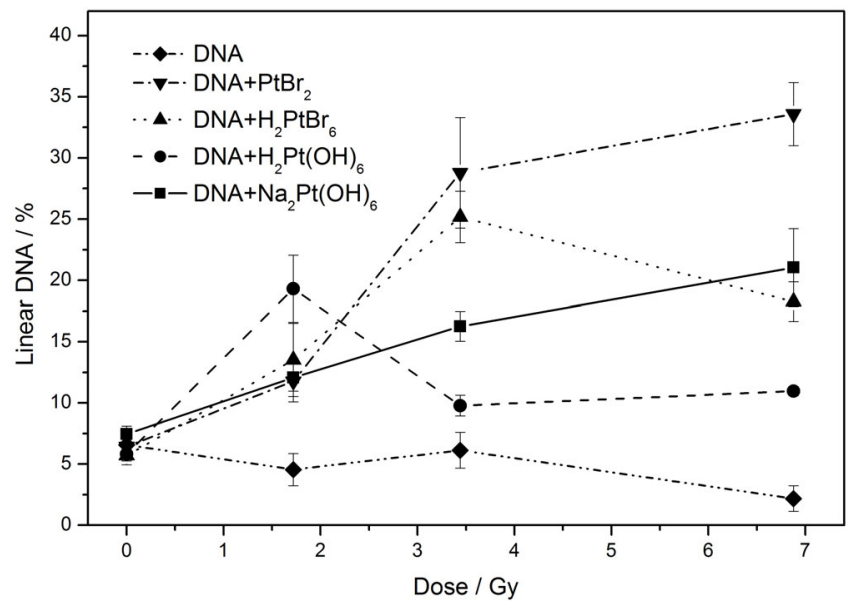

Fig. 6. Percentage amount of linear DNA form as a function of X-ray radiation dose for pure DNA and DNA with platinum compounds attached. Curves are guides to the eye.

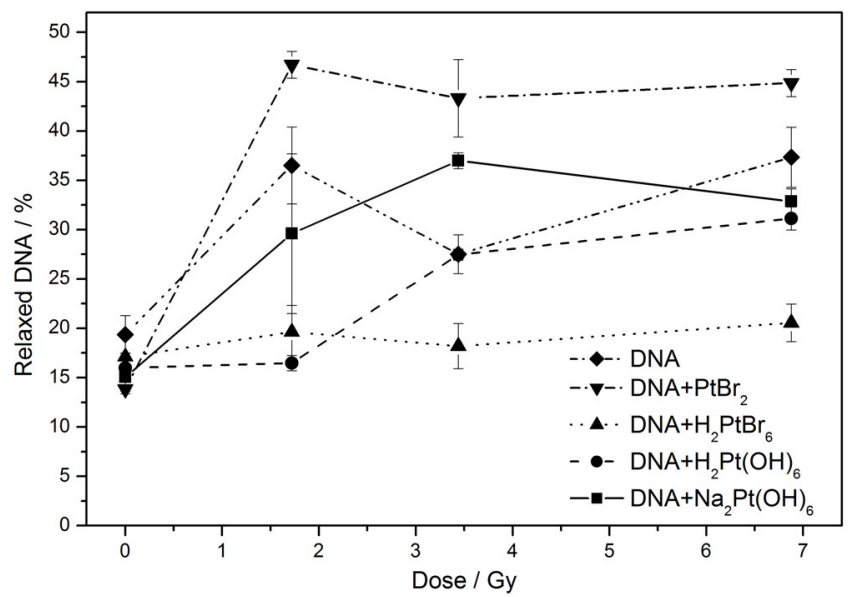

Fig. 7. Percentage amount of relaxed DNA form as a function of X-ray radiation dose for pure DNA and DNA with platinum compounds attached. Curves are guides to the eye. at 7 Gy radiation dose with respect to unmodified irradiated plasmid DNA.

The mechanism by which DNA damage is induced by radiation in the presence of investigated compounds needs to be explored. Since the highest levels of damage were obtained for $\mathrm{PtBr}_{2}$, the authors focused on the mode of action of this compound. The most probable pathway, due to a positive electron affinity of bromine $(3.363 \mathrm{eV})$ is dissociative electron attachment to $\mathrm{PtBr}_{2}$. The electron attachment studies have already been reported for electron energy range from 0 to $10 \mathrm{eV}$ [13] and $\mathrm{Br}^{-}$ion formation has been reported. The predominant channels for the dissociation of $\mathrm{PtBr}_{2}$ molecule were found at $1.2 \mathrm{eV}$ and assigned to $\mathrm{Br}^{-}+\mathrm{PtBr}$ formation and at $7.0 \mathrm{eV}$, where a $\mathrm{Br}^{-}+\mathrm{Pt}+\mathrm{Br}$ dissociation mechanism was attributed.

In case of the anhydrous films irradiated with X-ray, although the possible damage pathway was attributed to the low energy electron impact, another mechanisms may be predominant in aqueous environment. Water surrounding would allow also for hydroxyl radical formation with assist of the investigated compounds that may act as catalysts in the radical formation process. Nonetheless, anhydrous conditions correspond very well to the environment in the close proximity of DNA in the cell, where the interactions take place at the molecular level.

Although the mechanism is not yet fully understood, and thermodynamical studies of interactions of these compounds $\left(\mathrm{PtBr}_{2}\right.$ in particular) with DNA are planned, the present data implies that there is a potential for suggested compounds to be used as radiosensitizers in radiation therapy. Based on the data presented here, it is possible that when compounds of interest are introduced into cellular environment, i.e. as surface modification of carriers, such as nanoparticles, even higher levels of damage may be obtained.

MAS would like to acknowledge the COST Action CM0601 and Young Scientists Programme grant WAR/342/171 for supporting her visits to the Open University. SP gratefully acknowledges financial support from Engineering and Physical Sciences Research Council EPSRC in the form of a Postdoctoral Fellowship (EP/D067138/1). The research leading to these results has received funding from the European Community's Seventh Framework Programme (FP7/2007-2013) under grant agreement No. 226716.

M.A.Ś. performed sample preparation and data analysis, experiments with UV and X-rays and wrote the manuscript. S.P. performed experiments with X-rays and participated in editing and revising of the manuscript. J.G. performed X-ray irradiations. S.V.H. performed experiments with UV and participated in editing and revising of the manuscript. N.J.M. participated in editing and revising of the manuscript.

\section{References}

1. T.S. Lawrence, A.W. Blackstock, C. McGinn, Semin. Radiat. Oncol. 13, 13 (2003)

2. B. Boudaiffa, P. Cloutier, D. Hunting, M. Huels, L. Sanche, Science 287, 1658 (2000) 
3. Y.P. Ho, S.C.F. Au-Yeung, K.K.W. To, Med. Res. Rev. 23, 633 (2003)

4. J. Reedijk, Eur. J. Inorganic Chem. 2009, 1303 (2009)

5. G. Chu, J. Biol. Chem. 269, 787 (1994)

6. M. Rezaee, D.J. Hunting, L. Sanche, Int. J. Radiat. Oncol. Biol. Phys. 87, 847 (2013)

7. M. Maeda, K. Kobayashi, K. Hieda, Int. J. Radiation Biol. 80, $841(2004)$

8. C. Le Sech, K. Takakura, C. Saint-Marc, H. Frohlich, M. Charlier, N. Usami, K. Kobayashi, Radiation Research 153, 454 (2000)

9. A.T.C. Chan, S.F. Leung, R.K.C. Ngan, P.M.L. Teo, W.H. Lau, W.H. Kwan, E.P. Hui, H.Y. Yiu, W. Yeo, F.Y. Cheung, K.H. Yu, K.W. Chiu, D.T. Chan, T.S.K. Mok, S. Yau, K.T. Yuen, F.K.F. Mo, M.M.P. Lai, B.B.Y. Ma, M.K.M. Kam, T.W.T. Leung, P.J. Johnson, P.H. Choi, B.C. Zee, J. Natl. Cancer Institute 97, 536 (2005)

10. M.R. Detty, S.L. Gibson, S.J. Wagner, J. Med. Chem. 47, 3897 (2004)

11. M.A. Bagshaw, R.L. Doggett, K.C. Smith, H.S. Kaplan, T.S. Nelsen, Am. J. Roentgenol. Radium Ther. Nucl. Med. 99, 886 (1967)

12. M.A. Śmiałek, S. Ptasińska, J. Gow, C. Da Pieve, N.J. Mason, Eur. Phys. J. D 68, 1 (2014)
13. K. Tanzer, A. Pelc, S. Huber, M.A. Śmiałek, P. Scheier, M. Probst, S. Denifl, Int. J. Mass Spectrom. 365-366, 152 (2014)

14. M.A. Śmiałek, S.V. Hoffmann, M. Folkard, K.M. Prise, D.E.G. Shuker, N.S. Braithwaite, N.J. Mason, Radiation Damage in Biomolecular Systems 101, 12020 (2008)

15. M.A. Śmiałek, S.A. Moore, N.J. Mason, D.E.G. Shuker, Radiation Research 172, 529 (2009)

16. K. Kobayashi, N. Usami, I. Sasaki, H. Frohlich, C. Le Sech, Nucl. Instrum. Methods B 199, 348 (2003)

17. M.A. Śmiałek, R. Balog, N.C. Jones, D. Field, N.J. Mason, Eur. Phys. J. D 60, 31 (2010)

18. M.A. Śmiałek, N.C. Jones, R. Balog, N.J. Mason, D. Field, Eur. Phys. J. D 62, 197 (2011)

Open Access This is an open access article distributed under the terms of the Creative Commons Attribution License (http://creativecommons.org/licenses/by/4.0), which permits unrestricted use, distribution, and reproduction in any medium, provided the original work is properly cited. 